Journal of Global Business and Management Review Vol. 1 No. 2, Desember 2019

e-ISSN: 2685-3426

\title{
Factors Influencing College Student's Financial Literacy
}

\author{
Lady \\ Management Department, Universitas Internasional Batam \\ Jl. Gajah Mada, Baloi Sei Ladi Batam 29442 \\ email: ladymilano3@gmail.com
}

\begin{abstract}
Awareness of financial knowledge in this era, especially college students, is still scarce. College students are one part of society which increasing each year in numbers and would have strong impact on the economy of a country. College student is one level before get into the working level, which means they have to be more able to depend on their own self in managing their own finances.This study's purpose is to analyze factors which affect financial literacy of college students in Indonesia. The independent variables used are money management, financial behavior, influence, attitude, and investment. This study survey used google form which has 28 questions. The sample of this study is 350 college students taken randomly. The data tested by using SPSS program. This study results proved that all of the independent variables affect significantly positive on the financial literacy.
\end{abstract}

Keywords: financial attitude, behavior, influence, financial literacy, money management.

\section{BACKGROUND}

The global economy has improved and developed very rapidly in recent years. According to Central Bank of the Republic of Indonesia (Bank Sentral Republik Indonesia, 2017), the dynamics of the Indonesian economy in 2017 showed continued economic growth gradually. Overall it could be concluded that the increasing in Indonesia's economic growth in 2017 recorded $5.07 \%$ better than the achievement in 2016 of $5.03 \%$. Economic recovery in Indonesia encourages improvements in the level of welfare in the community's economy.

One factor that would affect the economic prosperity of the community is the way the Indonesian people implement financial management effectively and efficiently. The management of public finances varies throughout the world and the public must be smart in managing their personal financial assets. One cause that could affect a person's individual decisions in managing his personal financial assets is financial literacy.

Financial literacy (FL) is a basic concept in understanding money matter and its use in everyday life. FL combines understanding of daily life situations including insurance, credit, savings and loans (Sarigul, 2014). FL could be defined as understanding the language of money. Each individual must have FL to get rich or stabilize their financial situation. FL means that individuals could get benefit by the abilities and attitudes for understanding money management (MM) concepts, knowledge of financial institutions and also attitudes that enable management to be more responsibly effective in their financial matters (Mohammed \& Salleh, 2017).

Considering that Indonesia is a developing country, FL has special relevance to the developing economy. Research conducted by the Otoritas Jasa Keuangan (Indonesia Financial Services 
Authority, 2017) on Indonesia's FL index stated that in 2013 it reached $21.84 \%$ and in 2016 Indonesia's FL rate reached $29.66 \%$. The economic of a city could improve the financial condition of its citizens by achieving a higher level of economic growth. FL could improve the financial wealth of a person subsequently by financial decision making (Agarwalla, Barua, Jacob, \& Varma, 2013).

FL is important part of financial behaviour (FB). FL of each individual varies when the individual itself has a different level. This study uses a sample population of college students, where college student is a component that could affect FL in a country. Research conducted by OJK (Kontan, 2014), showed that public access to the financial industry in Indonesia is still low. The literacy rate in Indonesia is only $20 \%$, the results explain that in Indonesia the percentage is far different from the Philippines which reaches 27\%, Malaysia reaches $66 \%$, Thailand reaches $73 \%$, and also Singapore for even 98\%. Some developed countries still provide education about FL to college students in these countries, for example, such as Canada (Government of Canada, 2018).

Batam is a city with rapid economic development, and is close to the borders of Singapore and Malaysia. Batam has the highest Minimum Wages (Minimum City Wages) in Riau Islands (Tribun Batam, 2018). The city laws and restrictions make economic growth of the city developed faster than other big cities in Indonesia. Being close to neighbour country which has superb economy condition, makes the citizens of Batam began to be influenced.

Currency differences are fairly high, makes the citizens have to spend more funds to visit Singapore. Currency differences could be a factor that could affect the lifestyle of Batam citizens. The influence that could be felt is that it could result in lack of public knowledge and awareness for the way of financial management itself. People would prefer to save money for traveling in neighboring countries just to spend time.

Awareness of financial knowledge, especially on college students is still very low. College students is pre-workforce level, who should be even more depend on their own self, for managing their own finances. The importance of FL among young people is increasing. Young people are especially faced with changes made in the financial sector because they are increasingly faced with opportunities for various types of financial offers, for example: student loans, debit and credit, interest-free payment options (Lusardi et al., 2010). Another motivation for student FL is attitude towards money. This factor would differentiate each college student according to the level they consider money to be important. They would want to be literate in finance depending on how money is mattered for them (Albeerdy \& Gharleghi, 2015).

The importance of having FL skill is an important basis for individuals to avoid and solve financial problems, which are very important for a wealthy, healthy and happy life. Even more, lack of FL could cause individuals to become involved in higher levels of financial problems in college life, which would significantly affected their current and future families, and their lives (Sarigul, 2014).

On the other hand, financial knowledge would be more important at a higher level of education (Thapa \& Nepal, 2015). Three behavioral, FI, and FA variables have an influence on FL. The variables stated influential means that college students' financial knowledge could be enhanced by their attitude towards finance. College 
students who are financially aware tend to be more financially knowledgeable. In addition, college students' financial knowledge also varies with how they are involved in financial activities and how they affect them.

Fatoki (2014) conducted a study on FL in employees in South Africa. The independent variables are demographic, knowledge, MM, and FA and FB.

Sarigul (2014) conducted research on students about FL. The independent variables are banking general knowledge, saving and spending, risk-rate and insurance, and investing need.

Heenkenda (2015) conducted a study on FL in Sri Lanka. The independent variables are saving behavior, investment and payment mechanisms, awareness on financial products, risk management and pension funds, and MM.

Chmelikova (2015) conducted a study on FL at Masaryk University Czech Republic. The independent variables are financial knowledge, FB, and FAs.

Kalmi and Ruuskanen (2015) conducted a study on FL in Finland. The independent variables are financial knowledge, $\mathrm{FB}$, and FA.

Srividya and Susana (2016) conducted a study of the factors that affect FL in employees in India. The independent variables are FB and knowledge.

Isomidinova, Singh, and Singh (2017) conducted a study on FL in which the target population was students in Uzbekistan. The independent variables are education, financial socialization, and MM.

Mohammed and Salleh (2017) conducted research on factors that influence FL in students in Malaysia. The independent variables are academic courses, investment, demographic and MM.

Abdullah et al. (2017) conducted a study of factors that influence FL in students at
UiTM Jengka Campus. The independent variables are family FI, FA, FB and knowledge.

Choudhary and Kamboj (2017) conducted a study on FL of respondents aged over 20 years old. The independent variables are FB, FAs, and knowledge.

Venkataraman and Venkatesan (2018) conducted research on FL of employees. The independent variables are FB, FI, FA, and knowledge.

\section{Financial Literacy}

Definition of FL is understanding and knowing the basic economic and financial concepts, and also has the ability to use the knowledge in managing financial resources (Thapa \& Nepal, 2015).

Many studies report that the level of FL among university students and adults is easily seized. Some of them need to do part-time job because of the increased cost of financing higher education and others. Serious attention must be paid to the level of FL in order to avoid problems and the main implications on individual FL. In addition, people who are still lacking in financial knowledge tend to make bad decisions which could affect their consumption (Wajhi, Yunus, \& Ripain, 2018).

\section{Financial Behavior on Financial Literacy}

FB is an indispensable element of FL and is definitely the most important element. Someone has knowledge and is also positive in their attitude through financial problems, their future financial wealth depends on their behavior in using money in their daily activities (Choudhary \& Kamboj, 2017). Shopping habits, keeping shopping records, using money savings, managing money when there are problems, financial services taken and the use of extra income are the main aspects of FB (Thapa \& Nepal, 2015). 
Previous studies have explained that the higher person's FB, the better their financial well-being than those with low FL.

$\mathrm{H}_{1}$ : Financial behaviour has a significant positive effect on the FL.

\section{Financial Influence on Financial Literacy}

Generally, the main part for college student outreach are family members, peers, school friends and social media. Socialization agents are found throughout a person's life cycle (Isomidinova et al., 2017). The habits of parents, friends and social media could affect a child's FL so that children must obtain a proper education about finance (Dube \& Asthana, 2017).

Albeerdy and Gharleghi (2015) stated that there is a relationship between FI variables with FL.

$\mathrm{H}_{2}$ : Financial influence has a significant positive effect on the FL.

\section{Financial Attitude on Financial Literacy}

FA is an important element of FL, because it affects people's FB. Preferences for saving, consuming, and preferences for making long-term financial plans, are used to capture respondents' attitudes towards financial management (Choudhary \& Kamboj, 2017).

$\mathrm{H}_{3}$ : Financial attitude has a significant positive effect on the FL.

\section{Money Management on Financial Literacy}

To achieve a quality life as working adults, MM skills play an important role because college students would influence the way they manage money throughout their lives (Shaari, Hasan, Mohamed, \& Sabri, 2013). Research by Boyland and Warren (2013) states that personal MM is very important for college students. Previous studies considered MM as an independent variable that could affect the level of FL.

$\mathrm{H}_{4}$ : Money management has a significant positive effect on the FL.

\section{Investment on Financial Literacy}

Investment is a commitment of money or capital to buy financial instruments or other assets to produce profitable profits in the form of interest, income, or appreciation of the value of the instrument. Investments involve individuals or organizations in making decisions such as property, commodities, stocks, bonds, or foreign currencies that have a certain level of risk and could provide a return on investment for a certain period (Shaari et al., 2013). Study of Shaari et al. (2013) state that there is an investment relationship with FL.

$\mathrm{H}_{5}$ : Investment has a significant positive effect on the FL.

\section{RESEARCH METHODS}

Based on the research objectives, this study is an explanatory study of the determinants of FL among college students in Batam, Indonesia. This study population is college students in Batam. The sampling method used in this study is the questionnaire data collection method. The questionnaire were distributed to 350 college students.

Questionnaires were distributed to students from several universities, namely Politeknik Negeri Batam, Ibnu Sina Batam, Universitas Internasional Batam, Universitas Batam, Universitas Maritim Raja Ali Haji, Universitas Universal, and Universitas Putera Batam. The number of questionnaires was distributed randomly without dividing the number of questionnaires to be distributed to each university. The number of samples taken using a ratio of 1:10 (Hair, Black, Babin, \& Anderson, 2014). Based on 28 questions that 
the researcher collated, it is needed total number of 280 respondents.

The dependent variable used in this study is FL and the independent variables are FB, FI, FA, MM and investment. The questions that researchers made came from previous research by Thapa and Nepal (2015) and Ambarkhane and Venkataramani (2015) who had previously conducted research. The scale being used in this study is the scale of Likert which shows 5 choices with the intention to show five points consisting of 1 for the strongly disagree, 2 which means disagree, 3 for the neutral, 4 which means agree, and 5 for the strongly agree.

\section{RESULTS AND DISCUSSIONS}

Table 1 contains questionnaire data distributed, received and a questionnaire which are used in this study.

\section{Table 1 Respondent Statistics Data}

\begin{tabular}{lc}
\hline \multicolumn{1}{c}{ Descriptions } & Questionnaire \\
\hline $\begin{array}{l}\text { Questionnaire were } \\
\text { distributed }\end{array}$ & 350 \\
$\begin{array}{l}\text { Questionnaire which is not } \\
\text { filled in completely }\end{array}$ & 0 \\
$\begin{array}{l}\text { The outlier questionnaire } \\
\text { contained }\end{array}$ & 7 \\
$\begin{array}{l}\text { Questionnaire are used for } \\
\text { analysis }\end{array}$ & 343 \\
\hline Source: Data processed (2018).
\end{tabular}

Table 2 Demographic of Respondents by Gender

\begin{tabular}{lcc}
\hline Gender & Amount & Percentage \\
\hline Men & 141 & $31.1 \%$ \\
Women & 202 & $58.9 \%$ \\
\hline Total & 343 & $100 \%$ \\
\hline
\end{tabular}

Source: Data processed (2018).

Table 3 Demographic of Respondents by Age

\begin{tabular}{lcc}
\hline Age & Amount & Percentage \\
\hline$<18$ years old & 13 & $3.8 \%$ \\
19-22 years old & 306 & $89.2 \%$ \\
$>23$ years old & 24 & $7 \%$ \\
\hline Total & 343 & $100 \%$ \\
\hline
\end{tabular}

Source: Data processed (2018).

Table 4 Demographic of Respondents Based on University

\begin{tabular}{lcc}
\hline University & Amount & Percentage \\
\hline Ibnu Sina Batam & 10 & $2.9 \%$ \\
Politeknik Negeri Batam & 19 & $5.5 \%$ \\
Universitas Batam & 29 & $8.5 \%$ \\
Universitas Internasional & 189 & $55.1 \%$ \\
Batam & & \\
Universitas Riau & 6 & $1.7 \%$ \\
Kepulauan & & \\
Universitas Putera Batam & 68 & $19.8 \%$ \\
Universitas Universal & 22 & $6.4 \%$ \\
\hline Total & 343 & $100 \%$ \\
\hline Source: Data & &
\end{tabular}

Source: Data processed (2018).

Table 5 Demographic of Respondents Based on Student Status

\begin{tabular}{lcc}
\hline Status & Amount & Percentage \\
\hline Student worker & 296 & $86.3 \%$ \\
Full time student & 19 & $5.5 \%$ \\
$\begin{array}{l}\text { Students or parents own } \\
\text { business owners }\end{array}$ & 28 & $8.2 \%$ \\
\hline Total & 343 & $100 \%$ \\
\hline
\end{tabular}

Source: Data processed (2018).

Table 6 Demographic of Respondents Based on Academic Study Program

\begin{tabular}{lcc}
\hline Study Program & Amount & Percentage \\
\hline Accounting & 78 & $22.7 \%$ \\
Legal studies & 30 & $8.7 \%$ \\
Management & 173 & $50.4 \%$ \\
Tourism & 2 & $0.6 \%$ \\
Information Systems & 38 & $11.1 \%$ \\
Civil Engineering & 22 & $6.4 \%$ \\
\hline Total & 343 & $100 \%$ \\
\hline Source: Data processed (2018).
\end{tabular}

Table 7 Demographic of Respondents Based on Monthly Income

\begin{tabular}{lcc}
\hline Monthly income & Amount & Percentage \\
\hline <IDR 4,000,000 & 110 & $32.1 \%$
\end{tabular}




\begin{tabular}{lrr} 
IDR $4,000,001-10,000,000$ & 219 & $63.8 \%$ \\
>IDR $10,000,001$ & 14 & $4.1 \%$ \\
\hline Total & 343 & $100 \%$ \\
\hline
\end{tabular}

Source: Data processed (2018).

From the results of testing of 350 respondents produce data with Z-score values not exceeding -3 and 3 . The results of this outlier test prove that there are data which deviate were 7 questionnaires out of 350 questionnaires distributed.

Table 8 Reliability Test

\begin{tabular}{lcc}
\hline Questions & Alpha & Information \\
\hline$F B$ & 0.719 & Reliable \\
$F I$ & 0.791 & Reliable \\
$F A$ & 0.711 & Reliable \\
$M M$ & 0.705 & Reliable \\
$I$ & 0.767 & Reliable \\
$F L$ & 0.703 & Reliable \\
\hline
\end{tabular}

Source: Data processed (2018).

Table 9 Normality Test

\begin{tabular}{|c|c|c|}
\hline $\begin{array}{l}\text { Normality } \\
\text { test }\end{array}$ & $\begin{array}{c}\text { Asymp. Sig. } \\
\text { (2-tailed) }\end{array}$ & Conclusion \\
\hline $\begin{array}{l}\text { Kolmogorov } \\
\text { Smirnov }\end{array}$ & 0.075 & $\begin{array}{l}\text { Data is } \\
\text { normally } \\
\text { distributed }\end{array}$ \\
\hline Table $10 \mathrm{H}$ & Source: Data processed (2018). & Table 10 Heteroscedasticity Test \\
\hline Model & Sig. & Conclusion \\
\hline FB & 0.375 & Homoscedasticity \\
\hline FI & 0.100 & Homoscedasticity \\
\hline FA & 0.352 & Homoscedasticity \\
\hline MM & 0.943 & Homoscedasticity \\
\hline I & 0.89 & Homoscedasticity \\
\hline
\end{tabular}

Source: Data processed (2018).

Table 11 F-Test

\begin{tabular}{|c|c|c|c|c|}
\hline $\mathrm{F}$ & Sig & & & \\
\hline 28.373 & 0.000 & & & \\
\hline \multicolumn{5}{|c|}{ Source: Data processed (2018). } \\
\hline \multicolumn{5}{|c|}{ Table 12 t-test } \\
\hline Variable & B & $\mathrm{t}$ & Sig. & Results \\
\hline
\end{tabular}

\begin{tabular}{|c|c|c|c|c|}
\hline FB & 0.187 & 3.476 & 0.001 & $\mathrm{H} 1 \mathrm{is}$ \\
\hline & & & & $\begin{array}{l}\text { significantly } \\
\text { positive }\end{array}$ \\
\hline FI & 0.92 & 1.991 & 0.477 & $\begin{array}{l}\mathrm{H} 2 \text { is } \\
\text { significantly } \\
\text { positive }\end{array}$ \\
\hline FA & 0.359 & 6.652 & 0.000 & $\begin{array}{l}\mathrm{H} 3 \text { is } \\
\text { significantly } \\
\text { positive }\end{array}$ \\
\hline MM & 0.94 & 2.020 & 0.444 & $\begin{array}{l}\mathrm{H} 4 \text { is } \\
\text { significantly } \\
\text { positive }\end{array}$ \\
\hline I & 0.196 & 4.259 & 0.000 & $\begin{array}{l}\mathrm{H} 5 \text { is } \\
\text { significantly } \\
\text { positive }\end{array}$ \\
\hline
\end{tabular}

Source: Data processed (2018).

H1: There is a significant positive effect between financial behaviour on financial literacy.

Based on the significant value of the FB variable shows that the variable has a significant influence on the dependent variable FL. These results prove that hypothesis 1 has a significant positive effect on the dependent variable FL with the significant value of 0.001 is lower than 0.05 and the beta yield is 0.187 . Previous studies state that there was a significant positive effect between FB on FL. The result prove that students with high FB possess better FB. Students who have good FB tend to be more understanding and able to manage their personal finances.

$\mathrm{H} 2$ : There is a significant positive influence between financial influence on financial literacy.

Based on the significant value of the FI variable, it shows that the variable has a significant positive effect on the dependent variable FL. These results prove that hypothesis 2 has a significant positive effect on the dependent variable FL with a significant value of 0.047 which is less than 0.05 and the beta is 0.092 .

Previous studies state that there was a significant positive influence between FI and 
FL. Students who have more opportunities to discuss and observe their parents and peers are more likely to save and make budgeting funds. Therefore, this shows how family and peers have a big influence on student FL.

H3: There is a significant positive effect between financial attitude on financial literacy.

Based on the significant value of the FA variable shows that the variable has a significant positive effect on the dependent variable FL. This result prove that hypothesis 3 has a significant positive effect on the dependent variable FL with a significant value of 0,000 which is less than 0.05 and the beta is 0.359 .

Previous studies state that there was a significant positive effect between FA on FL. College students' financial knowledge could be enhanced by their attitude towards finance. College students who are aware of financial problems tend to be more knowledgeable financially. In addition, students' financial knowledge is no different from how they are involved in financial activities and what influences them.

H4: There is a significant positive effect between money management on financial literacy.

Based on the significant value of the variable MM shows that the variable has a significant positive effect on the dependent variable FL. This result prove that hypothesis 4 has a significant positive effect on the dependent variable FL with a significant value of 0.044 less which is less than 0.05 and the beta is 0.094 .

Previous research states that there is a significant positive effect between $\mathrm{MM}$ on FL. The result proved that the higher the percentage of $\mathrm{MM}$, the better financial management of a college student. Previous sudies stated that from the respondents surveyed, they considered themselves to be an efficient money managers, had a good understanding of finances or all that needed to be known in managing personal finances.

H5: There is a significant positive effect between investment on financial literacy.

Based on the significant value of the investment variable shows that this variable has a significant positive effect on the dependent variable FL. This result prove that hypothesis 5 has a significant positive effect on the dependent variable FL with a significant value of 0,000 which is less than 0.05 and the beta is 0.196 .

This result is in line with previous studies by Shaari et al., (2013) which states that there was an relationship between investment and FL. Previous studies state that there was a significant positive effect between investment on FL. Investment involves individuals in making choices, such as analyzing which investments have high or low risks and which investments could give high returns for a certain period of time.

Value adjusted $\mathrm{R}^{2}$ of 0.286 proved that $28.6 \%$ of the test results could be obtained that the dependent variable of a FL could be explained by the independent variables of $\mathrm{FB}$, FI, FA, MM, and investment. The remaining percentage of $71.4 \%$ is explained by other variables which are not used in this study.

\begin{tabular}{ccc}
\multicolumn{3}{l}{ Table 13 The Adjusted $\mathrm{R}^{2}$ Test } \\
\hline $\mathrm{R}^{2}$ & Adjusted $\mathrm{R}^{2}$ & SEE \\
\hline 0.296 & 0.286 & 2.61878 \\
\hline
\end{tabular}

Source: Data processed (2018).

\section{CONCLUSIONS}

This study purpose is to analyze the factors which influence FL of college students. With the dependent variable FL and also the independent variable FB, FI, FA, MM and 
investment. The purpose of this study is to find out what influences the behavior of a college student, so that the results of this study could be beneficial for students and also the community. The results of all 5 hypothesis showed that each independent variables in this study have significant positive effect to the FL. This means we have to give attention to the independent variables in purpose to increase college students' financial literacy.

Coverage of researchers is only for college students in Batam (a small part of Indonesia), so the results obtained could only represent Batam college students in terms of FL. The total effect which shown in Adjusted $\mathrm{R}^{2}$ test result was only $28.6 \%$ is quite low. So there are other independent variables which could give higher effect to FL.

Future studies could expand the sample size to reduce potential biases and improve its accuracy. This includes distributing questionnaires equally of a developed or developing country where different results could be obtained, or it could be compared. In addition, future researchers may include other variables, which could affect FL, such as banking general knowledge, saving and spending behaviour, banking system, risk level, and insurance.

\section{REFERENCES}

Abdullah, S., Mohammed, N. H., Salleh, S. M., Rashid, K. M., Syahirah, S. S., \& Kamal, M. (2017). Financial Literacy among UiTM's Students. J. Appl. Environ. Biol. Sci, 7(5S), 31-36.

Agarwalla, S. K., Barua, S. K., Jacob, J., \& Varma, J. R. (2013). Financial Literacy Among Working Young in Urban India. Ssrn.

https://doi.org/10.2139/ssrn.2338723

Albeerdy, M. I., \& Gharleghi, B. (2015). Determinants of the Financial Literacy among College Students in Malaysia.
International Journal of Business Administration, 6(3), 15-24. https://doi.org/10.5430/ijba.v6n3p15

Ambarkhane, D., \& Venkataramani, B. (2015). Financial Literacy Index for College Students. Journal of Symbiosis Centre for Management Studies, 3, 125.

Bank Sentral Republik Indonesia. (2017). Pertumbuhan Ekonomi. Retrieved from https://www.bi.go.id/id/publikasi/lapora ntahunan/perekonomian/Pages/LPI_201 7.aspx

Borodich, S., Deplazes, S., Kardash, N., \& Kovzik, A. (2010). Comparative Analysis Of The Levels Of Financial Literacy Among Students in The U.S, Belarus and Japan. Journal of Economics and Economic Education Research, 11(3), 71-86.

Boyland, J., \& Warren, R. (2013). Assessing the financial literacy of domestic and international college students, Paper 18. MBA Student Scholarship http://scholarsarchive.jwu.edu/mba_stud ent

Cameron, M. P., Calderwood, R., Cox, A., \& Lim, S. (2013). Personal Financial Literacy among High School Students in New Zealand, Japan and the USA, 12(3), 200-215. https://doi.org/10.2304/csee.2013.12.3.2 00

Cameron, M. P., Calderwood, R., Cox, A., Lim, S., \& Yamaoka, M. (2013). New Zealand Personal Financial Literacy Among High School Students in New Zealand, Japan and the United States Richard Calderwood Ashleigh Cox Steven Lim Michio Yamaoka Department of Economics Working Paper in Economics 13 / 04 March 2013 Corresponding A, 64(0). 
Chmelikova, B. (2015). Financial Literacy of Students of Finance: An Empirical Study from the Czech Republic. Nternational Journal of Social, Behavioral, Educational, Economic, Business and Industrial Engineering, 9(12), 4202-4205.

Choudhary, K., \& Kamboj, S. (2017). A Study Of Financial Literacy and Its Determinants: Evidence From India. Asian Journal of Accounting Perspectives 10 (2017), 10, 52-72.

Dewanty, N., \& Isbanah, Y. (2018). Determinants of the Financial Literacy: Case Study on Career Woman in Indonesia. Etikonomi 17(2), 285-296.

Dube, V. S., \& Asthana, P. K. (2017). A Comparative Study on Financial Literacy of Uttar Pradesh with Central Zone States in India. IOSR Journal of Business and Management (IOSR-JBM), 19(10), 22-27. https://doi.org/ 10.9790/487X-1910032227

Fatoki, O. (2014). The Financial Literacy of Micro Entrepreneurs in South Africa. Journal Social Science, 40(2), 195-212. https://doi.org/10.4324/9780203500736

Government of Canada. (2018). Financial literacy programs. Retrieved from https://www.canada.ca/en/financialconsumer-agency/services/financialliteracy-programs.html

Hair, J. F., Black, W. C., Babin, B. J., \& Anderson, R. E. (2014). Multivariate data analysis. Pearson custom library. https://doi.org/10.1038/259433b0

Heenkenda, S. (2015). Inequalities in the Financial Inclusion in Sri Lanka: An Assessment of the Functional Financial Literacy, (February 2014). https://www.researchgate.net/publication $/ 281409218$
Isomidinova, G., Singh, J., \& Singh, K. (2017). Determinants of financial literacy: a quantitative study among young students in Tashkent, Uzbekistan. Electronic Journal of Business \& Management, 2(1), 61-75.

Kadoya, Y., \& Khan, M. S. R. (2017). Explaining Financial Literacy in Japan : New Evidence using, 1-27. http://dx.doi.org/10.2139/ssrn.3067799

Kalmi, P., \& Ruuskanen, O. (2015). Financial Literacy and Retirement Planning in Finland. Journal of Pension Economics and Finance. https://www.researchgate.net/publication /319238343

Kontan. (2014). Baru 28\% mahasiswa dan pelajar melek keuangan. Retrieved from https://keuangan.kontan.co.id/news/baru -28-mahasiswa-dan-pelajar -melekkeuangan

Lusardi, A., \& Mitchell, O. S. (2011). Financial Literacy and Planning: Implications for Retirement Well Being. National Bureau of Economic Research. http://www.nber.org/papers/w17078

Lusardi, A., Mitchell, O. S., \& Curto, V. (2010). Financial Literacy among the Young, 44(2), 358-380. The Journal Of Consumer Affairs. http://www.mrrc.isr.umich.edu/ (734) 615-0422

Mohammed, N. H., \& Salleh, S. M. (2017). Financial Literacy among UiTM' s Students Financial Literacy among UiTM's Students, (December). Journal of Applied Environmental and Biological Sciences, https://www.researchgate.net/publication /321579093

Otoritas Jasa Keuangan. (2017). Strategi Nasional Literasi Keuangan Indonesia Revisit 2017. Retrieved from 
https://www.ojk.go.id/id/berita-dankegiatan/publikasi/Documents/Pages/Str ategi-Nasional-LiterasiKeuangan Indonesia-(Revisit-2017)-/SNLKI (Revisit 2017).pdf

Pillai, R., Carlo, R., D 'souza, R., \& Pillai, K. R. (2010). M P RA Financial Prudence among Youth Financial Prudence among Youth Financial Prudence among Youth, (22450). Retrieved from https://mpra.ub.uni-muenchen.de/22450/

Sabri, M. F., MacDonald, M., K.Hira, T., \& Masud, J. (2010). Childhood consumer experience and the financial literacy of college students in malaysia. Family \& Consumer Sciences Research Journal. https://doi.org/10.1111/j.15523934.2010 .00038

Sarigul, H. (2014). International handbook of financial literacy. International Handbook of Financial Literacy, 1-713. https://doi.org/10.1007/978-981-100360-8

Sarpong, B., Gyimah, P., \& Poku, K. (2018). Financial Literacy Assessment on Tertiary Students in Sub-Saharan Africa: A Ghanaian Perspective, (May). https://doi.org/10.5296/ijafr.v8i2.12928

Saunders, M., Lewis, P., \& Thornhill, A. (2008). Research Methods for Business Students. Research methods for business students. https://doi.org/10.1007/s13398014-0173-7.2

Shaari, N. A., Hasan, N. A., Mohamed, R. K. M., \& Sabri, M. A. J. M. (2013). Financial Literacy: a Study Among the University Students. Interdisciplinary Journal of Contemporary Research In Business, 5(2), 279.

Sohn, S., Joo, S., Grable, J. E., Lee, S., \& Kim, M. (2012). Adolescents ' fi nancial literacy: The role of financial socialization agents, fi nancial experiences, and money attitudes in shaping fi nancial literacy among South Korean youth. Journal of Adolescence, $1-12$.

https://doi.org/10.1016/j.adolescence.20 12.02.002

Srividya, D. V., \& Susana, D. (2016). Asian Research Consortium A Study on Consumer Attitude and Buying Behaviour towards Organized Retail Stores in Erode District. Asian Journal of Research in Social Sciences and Humanities, 6(5), 1038-1049. https://doi.org/10.1007/s10494-0099236-9

Thapa, B. S., \& Nepal, S. R. (2015). Financial Literacy in Nepal: A Survey Analysis from College Students. Nrb Economic Review, 26-28 Febr(February 2015), 49-74. https://doi.org/R34102478

Tribun Batam. (2018). UMK Batam 2019, Daftar Lengkap UMK di Kepri (Kepulauan Riau) dari Tertinggi hingga Terendah. Retrieved from http://jateng.tribunnews.com/2018/11/23 /umk-batam-2019-daftarlengkap -umkdi-kepri-kepulauan-riau-dari-tertinggihingga-terendah

Venkataraman, R., \& Venkatesan, T. (2018). Analysis of Factors Determining Financial Literacy using Structural Equation Modelling\#. SDMIMD Journal of Management, 9(1), 1-11. https://doi.org/10.18311/sdmimd/2018/1 9998

Wagner, J. F. (2015). An Analysis of The Effects of Financial Education On Financial Literacy and Financial Behaviors. Dissertations, Theses, and Student Research from the College of Business. http://digital commons.unl.edu/businessdiss 
Journal of Global Business and Management Review Vol. 1 No. 2, Desember 2019

e-ISSN: 2685-3426

Wajhi, A. N., Yunus, M., \& Ripain, N. (2018). Scale and Determinants of Financial Literacy in Kolej Universiti Islam Antarabangsa Selangor Students. Reports on Economics and Finance, 4(3), 125-137. https://doi.org/10.12988/ref.2018.8112 